\title{
Emission inventories and modeling requirements for the development of air quality plans. Application to Madrid (Spain)
}

\author{
Rafael Borge , Julio Lumbreras, Javier Pérez, David de la Paz, Michel Vedrenne, \\ Juan Manuel de Andrés, $M^{a}$ Encarnación Rodríguez
}

\section{H I G H L I G H T S}

- A comprehensive and flexible urban emission inventory was developed for Madrid.

- Options for multi-scale consistency are discussed (from European to street level).

- Urban background $\mathrm{NO}_{2}$ concentration levels well described by CMAQ (MB $-2.2 \mu \mathrm{g} / \mathrm{m}^{3}$ ).

- $\mathrm{NO}_{2}$ concentration levels in Madrid are dominated by local traffic (up to 90\%).

- A $31 \%$ reduction of $\mathrm{NO}_{\mathrm{X}}$ emissions may allow Madrid meeting the $\mathrm{NO}_{2}$ European standards.

\begin{abstract}
A B S T R A C T
Modeling is an essential tool for the development of atmospheric emission abatement measures and air quality plans. Most often these plans are related to urban environments with high emission density and population exposure. However, air quality modeling in urban areas is a rather challenging task. As environmental standards become more stringent (e.g. European Directive 2008/50/EC), more reliable and sophisticated modeling tools are needed to simulate measures and plans that may effectively tackle air quality exceedances, common in large urban areas across Europe, particularly for $\mathrm{NO}_{2}$. This also implies that emission inventories must satisfy a number of conditions such as consistency across the spatial scales involved in the analysis, consistency with the emission inventories used for regulatory purposes and versatility to match the requirements of different air quality and emission projection models. This study reports the modeling activities carried out in Madrid (Spain) highlighting the atmospheric emission inventory development and preparation as an illustrative example of the combination of models and data needed to develop a consistent air quality plan at urban level. These included a series of source apportionment studies to define contributions from the international, national, regional and local sources in order to understand to what extent local authorities can enforce meaningful abatement measures. Moreover, source apportionment studies were conducted in order to define contributions from different sectors and to understand the maximum feasible air quality improvement that can be achieved by reducing emissions from those sectors, thus targeting emission reduction policies to the most relevant activities. Finally, an emission scenario reflecting the effect of such policies was developed and the associated air quality was modeled.
\end{abstract}

\section{Introduction}

Modeling is an essential tool for the development of atmospheric emission abatement measures and Air Quality Plans (AQP). Frequently, these plans are related to urban environments where the emission sources as well as the exposed population are concentrated (Vlachokostas et al., 2009; EEA, 2011). Developing a set of reliable tools for air quality modeling at urban scale is a very challenging task due to the fact that urban environments are particularly complex. The environments are characterized by the presence of several pollutants emitted from multiple sources. Moreover, a series of different spatial and temporal scales are involved in the chemical transformation and transport processes of such pollutants. The inherent complexity of urban environments requires simulation tools to assess air quality levels to be able to support the analysis and evaluation of a variety of policies and emission abatement measures (Denby et al., 2011).

As environmental standards increase in strictness, more reliable modeling tools are needed to simulate any measure or plan intended to effectively tackle air quality exceedances. This fact implies the need to count on reliable and flexible inventories that integrally describe the emissions of urban sources, in accordance with the requirements of 
the applied air quality models (FAIRMODE, 2010). There are a number of global and regional inventories that have been found useful to support air quality modeling studies (Pouliot et al., 2012; European Commission, 2009; Vestreng, 2003). Even at the urban scale, numerous inventories have been developed all over the world (Sturm et al., 1999; Sowden et al., 2008; Venegas and Mazzeo, 2006; Ho and Clappier, 2011 among others). However, there is a lack of harmonized and scientifically sound methodologies to address the compilation of urban scale inventories and to secure their consistency with existing regional and national inventories (Vedrenne et al., 2012).

Nitrogen dioxide is a clear example of a legislated air pollutant (EU Directive 2008/50/EC) with important implications for human health (Latza et al., 2009) that still poses an important challenge. Despite recent efforts made in Europe, ambient air concentrations of $\mathrm{NO}_{\mathrm{X}}$ lag clearly behind the decreasing trend of $\mathrm{NO}_{\mathrm{X}}$ emissions (Guerreiro et al., 2010). This is relevant for the compliance of $\mathrm{NO}_{2}$ limit values, especially in urban environments. In 2010, 22 of the 27 EU Member States recorded exceedances of the limit value (EEA, 2012). Madrid (Spain) is one of the European cities where $\mathrm{NO}_{2}$ is the main air quality issue and is legally bounded to develop an $\mathrm{AQP}$ to meet the required limit values (further details are provided in Section 2).

Specifically from the perspective of emission inventories, $\mathrm{NO}_{\mathrm{X}}$ are also especially interesting since actual emission rates and chemical speciation depend to a large extent on how engines and combustion devices are operated and maintained as well as technological changes. This is particularly true for the road transport sector (Lee et al., 2013; Simmons and Seakins., 2012; Liu et al., 2009; Grice et al., 2009) which often constitutes the single most important source of $\mathrm{NO}_{\mathrm{X}}$ emissions in urban environments. In addition, urban scale inventories usually need a fine spatial and temporal resolution, which cannot be achieved by downscaling methods or top-down inventories. This implies that methods to relate emissions with transport patterns and relevant activity data are need in the compilation of local inventories (Ariztegui et al., 2004).

The present study describes the modeling activities carried out for Madrid (Spain). The developed work is an illustrative example of the combination of models and emission data that are needed to provide a comprehensive picture of air quality at the urban scale and thus, provide the basis for the formulation of AQP.

\section{Case Study}

Madrid is the capital and largest city in Spain, located in the center of the Iberian Peninsula with a total population of 5 million people in its metropolitan area. Despite the experienced population and traffic increase, air quality levels have improved in the city over the last decade. However, some pollutants like nitrogen dioxide $\left(\mathrm{NO}_{2}\right)$ still exceed the limit values (LV) according to the European legislation. $\mathrm{The}^{\mathrm{NO}}$ annual average recorded in most of the city's traffic air quality monitoring stations is usually above the $\operatorname{LV}\left(40 \mu \mathrm{g} / \mathrm{m}^{3}\right)$. This phenomenon is basically attributed to heavy traffic levels and to a strong dieselization of the fleet in recent years (Kassomenos et al., 2006).

In $2007,80 \%$ of the monitoring stations exceeded the ambient air quality standards. As a consequence, important modeling efforts are being made to improve the knowledge about air quality dynamics in Madrid and to identify the most effective abatement options to meet the $\mathrm{NO}_{2} \mathrm{LV}$ in the near future. This work constitutes an extension of the integrated assessment modeling activities in Spain, which intends to provide useful tools for local policymakers to this respect (Borge et al., 2007). In particular it reports on the methods and results of the development and assessment of a local AQP enacted by the Madrid municipality (Madrid City Council, 2012) with a temporal horizon up to 2015. According to the latest data available (year 2012), the situation has improved substantially although 10 (out of 24) monitoring stations still report $\mathrm{NO}_{2}$ annual means above the LV.

\section{Methods}

\subsection{Mesoscale modeling}

Urban concentration levels depend on the atmospheric phenomena that occur at different spatial scales, namely from international scales of thousands of $\mathrm{km}$ to street levels of a few meters (Monteiro et al., 2007). Additionally, these levels present complex interactions with a large variety of chemicals in the atmosphere. Up to now, no single model can describe these processes consistently so a combination of models is needed to address such description. Moreover, the choice of the model is basically dependent on the purpose of the simulation. In this context, last-generation, 3D Eulerian models equipped with full photochemical schemes can consistently describe transport and transformation processes of $\mathrm{NO}_{\mathrm{X}}$ and tropospheric $\mathrm{O}_{3}$ (the main species involved in the complex dynamics of photochemical chemistry) from continental to urban scale.

The mesoscale modeling system is based on the Weather Research and Forecasting (WRF) (Skamarock and Klemp, 2008), the Sparse Matrix Operator Kernel Emissions (SMOKE) modeling system (Institute for the Environment, 2009), and the Community Multiscale Air Quality (CMAQ) (Byun and Ching, 1999; Byun and Schere, 2006). Details about specific configuration and adaptation to the Spanish conditions can be found respectively in Borge et al. (2008a, 2008b; 2010a).

Four nested domains (Fig. 1) were used in order to capture international, national, regional and local contributions to $\mathrm{NO}_{2}$ to ambient concentration in Madrid with a maximum resolution of $1 \mathrm{~km}^{2}$ (Table 1). Each domain used dynamic boundary conditions from its immediate mother domain, except D1 that was run with fixed lateral chemical boundary conditions (details regarding CMAQ boundary conditions can be found in Borge et al., 2010a). A similar nesting approach was applied for the simulation of meteorology. The mother domain for the WRF model (slightly larger than D1 shown in Fig. 1) was run with initial and boundary conditions from the National Centers for Environmental Prediction (NCEP) Global Tropospheric Analyses with $1^{\circ} \times 1^{\circ}$ spatial resolution and temporal resolution of $6 \mathrm{~h}$. This mesoscale configuration was found useful to describe urban background pollution levels, meeting the EU benchmarks for regulatory $\mathrm{NO}_{2}$ modeling. The model uncertainty according to the Relative Directive Error (RDE) for this application reaches $23.7 \%$ (hourly LV) and 22.4\% (annual LV), well below the maximum RDE criteria of $50 \%$ and $30 \%$, respectively (Fig. 2). This corresponds to a global mean bias (MB) of $-2.2 \mu \mathrm{g} / \mathrm{m}^{3}$, a mean fractional bias of $-14.1 \%$ and a global correlation factor ( $r$ ) of 0.63 .

\subsection{Hotspot modeling}

Despite a satisfactory performance of the mesoscale system, $\mathrm{NO}_{2}$ presents strong concentration gradients that cannot be reproduced by mesoscale Eulerian models since large concentration variations typically exist within the extension of a grid cell. Such gradients have been observed in many urban environments (e.g. Vardoulakis et al., 2011) including specific measurement campaigns with passive samplers performed in Madrid (Karanasiou et al., 2011). In order to depict street level concentration gradients, specific and local-scale tools are needed; either high-resolution flow models that can resolve the buildings or semi-empirical street canyon models able to capture this variability (Vardoulakis et al., 2003).

To this respect, CFD (Computational Fluid Dynamic) models are very expensive computationally and can only be applied to spatially and temporally restricted domains. For this reason, simpler, parameterized operational street canyon models are preferred for planning and regulatory purposes (Vardoulakis et al., 2007). Street-scale systems, such as the Operational Street Pollution Model (OSPM) (Berkowicz et al., 2008) used in this study, are based on a combined plume and box model that can simulate in-street emissions and dispersion (including traffic-induced turbulence) according to local building 

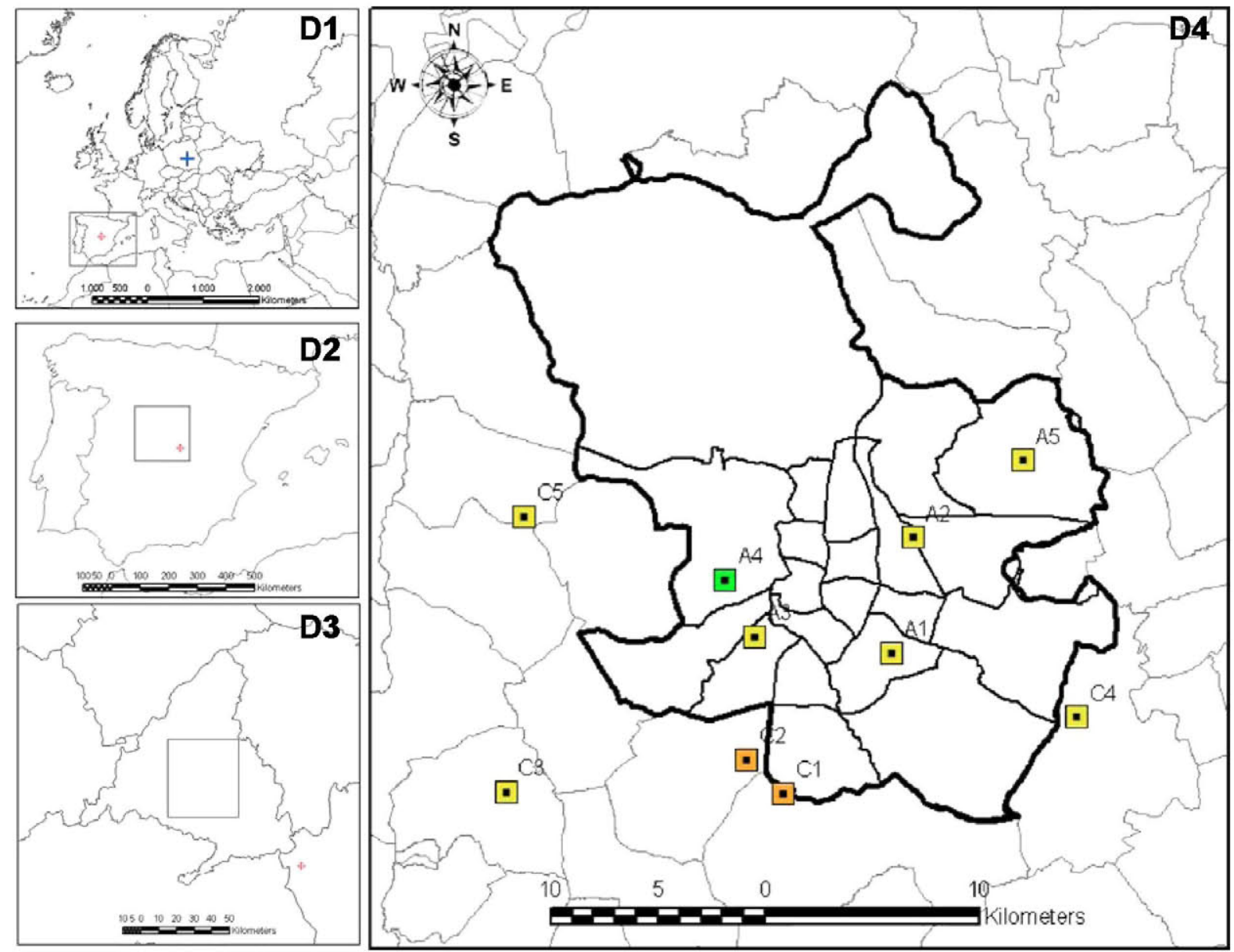

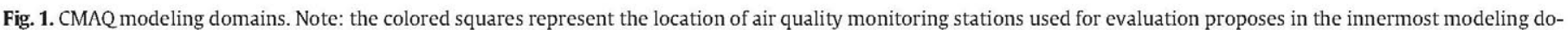

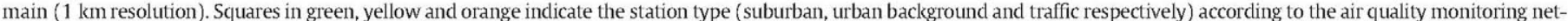

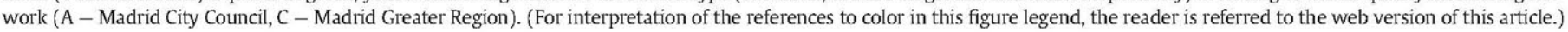

geometry and street configuration. Besides the short computational time requirements, these models provide a rough representation of very fast chemistry (i.e. primary $\mathrm{NO}$ oxidation depending on $\mathrm{O}_{3}$ background levels), which dominates $\mathrm{NO}_{2}$ levels at traffic locations. Street canyon models however, need to be carefully coupled to the mesoscale model system (meteorology, background concentration) in order to obtain a consistent representation of air quality.

In this study, outputs from WRF and CMAQ were used to provide wind conditions and pollution background concentration at roof level, inputs to which street canyon models are very sensitive. In addition, consistent emission data have to be used across the scales and models. In this application, a common traffic model is used to provide the activity data (intensity, fleet composition) and relevant variables (average speed, etc.) needed for traffic emission computation (as discussed in the next section). The results indicated that when properly fed (meteorology, background pollution and traffic conditions), the street-canyon model is able to achieve a reasonable performance ( $\mathrm{RDE}<20 \%$ ) even

Table 1

Spatial domains for the mesoscale modeling system.

\begin{tabular}{llcl}
\hline Domain & Geographic scope & X-Y dimensions $(\mathrm{km})$ & Horizontal resolution $(\mathrm{km})$ \\
\hline D1 & Europe & $6144 \times 5376$ & 48 \\
D2 & Iberian Peninsula & $1200 \times 960$ & 16 \\
D3 & Greater Madrid & $192 \times 192$ & 4 \\
& Region & & \\
D4 & Madrid Metropolitan & $40 \times 44$ & 1 \\
& Area & & \\
\hline
\end{tabular}

at heavily trafficked hotspots with hourly peak values close to $400 \mu \mathrm{g}$ $\mathrm{NO}_{2} / \mathrm{m}^{3}$, such as the traffic station illustrated in Fig. 3 .

The results obtained after identifying and analyzing this traffic hotspot within the city of Madrid strongly highlight the need of conducting such studies in order to estimate the effectiveness of specific policies and control measures as well as to evaluate the resulting technological improvements in vehicles (Beelen et al., 2009). To this respect, hotspot-modeling activities provide valuable information regarding the street level, which if overlooked, might originate ineffective legislative measures (Giannouli et al., 2011).

\subsection{Emission inventories}

For the completion of an efficient air quality management framework, the existence of a robust emission inventory is crucial (Moussiopoulos et al, 2009). Moreover, emissions constitute a key input to air quality models since they are deemed being one of the main sources of uncertainty (Russell and Dennis, 2010). This issue is also relevant for the analysis of alternatives to improve air quality in a given region in future years as a result of the implementation of emission abatement (FAIRMODE, 2010).

As for the implications related with multi-scale studies, emission estimates constitute one of the most challenging aspects. Emissionrelated inputs must be as detailed and specific as possible for the different domains involved in the simulation, and simultaneously they must be consistent across the scales (Borge et al., 2009). In addition, they have to be flexible and detailed enough to reflect the outcome of relevant measures and meet the modeling system requirements (Borge 


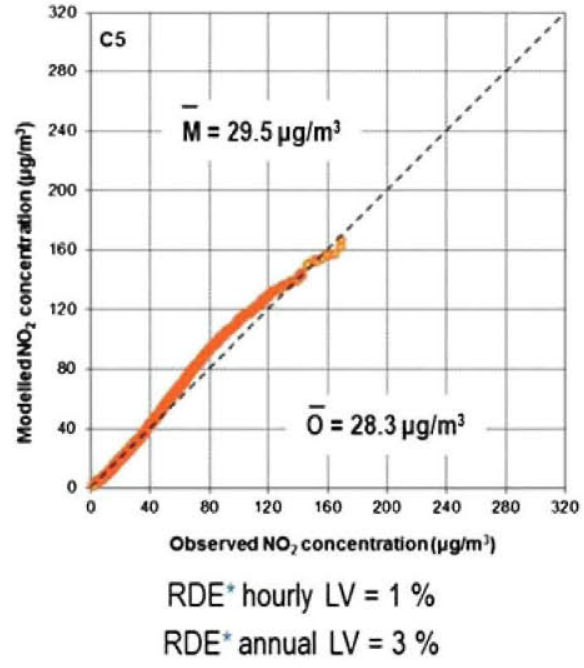

$M B=1.2 \mu g / m^{3} \quad M E=16.2 \mu g / m^{3} \quad r=0.608$
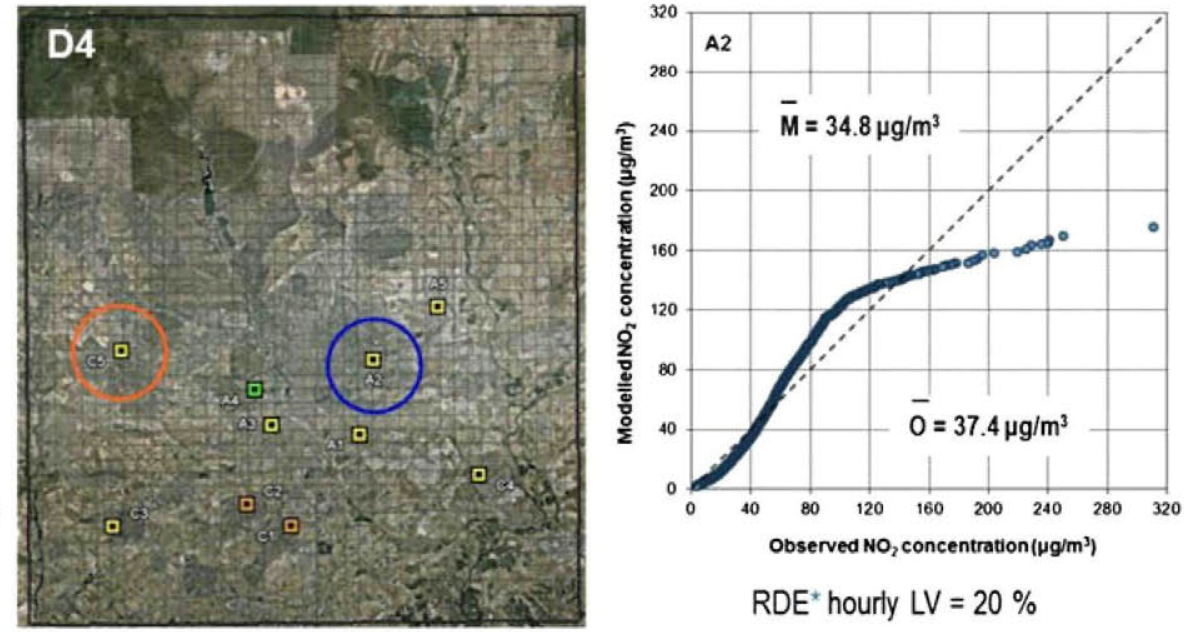

RDE $^{\star}$ hourly $L V=20 \%$

$\mathrm{RDE}^{\star}$ annual $\mathrm{LV}=6 \%$

$M B=-2.5 \mu g / m^{3} \quad M E=18.4 \mu g / m^{3} \quad r=0.608$

$\begin{gathered}\text { * Relative Directive Error (RDE) } \\ \text { Directive 2008/50/EC }\end{gathered} \quad \mathrm{RDE}=\frac{\left|\mathrm{O}_{\mathrm{LV}}-\mathrm{M}_{\mathrm{LV}}\right|}{\mathrm{LV}}$

where: $\mathrm{O}_{\mathrm{LV}}-$ closest observed concentration to the limit value concentration (LV)

$$
\mathrm{M}_{\mathrm{LV}} \text { - correspondingly ranked modelled concentration }
$$

Fig. 2. Computation and results of the Relative Directive Error (RDE) for the innermost domain and two examples for individual monitoring stations ( $C 5$ in the left and $A 2$ in the right). $\mathrm{C5}$ is an example of an urban background station. Although A2 is also labeled as an urban background site it is more influenced by direct traffic emissions. Mean error (MB) and error (ME) are larger but the correlation coefficient ( $\mathrm{r}$ ) is the same. According to the Directive 2008/50/EC, the uncertainty for $\mathrm{NO}_{2}$ modeling should be assessed by the Maximum RDE (MRDE) found at $90 \%$ of the available stations. The results for this application are $23.7 \%$ (hourly limit value) and $22.4 \%$ (annual limit value).

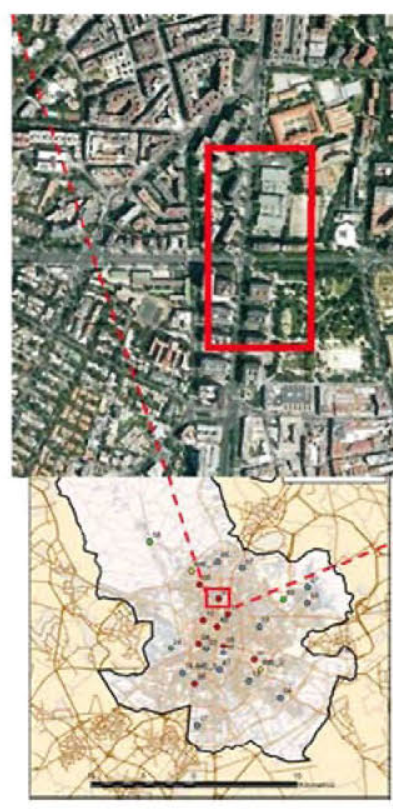

RDE hourly $L V=5 \%$

RDE annual $L V=13 \%$

$M B=5.0 \mu \mathrm{g} / \mathrm{m}^{3}$

$M E=22,8 \mu \mathrm{g} / \mathrm{m}^{3}$

$r=0,665$
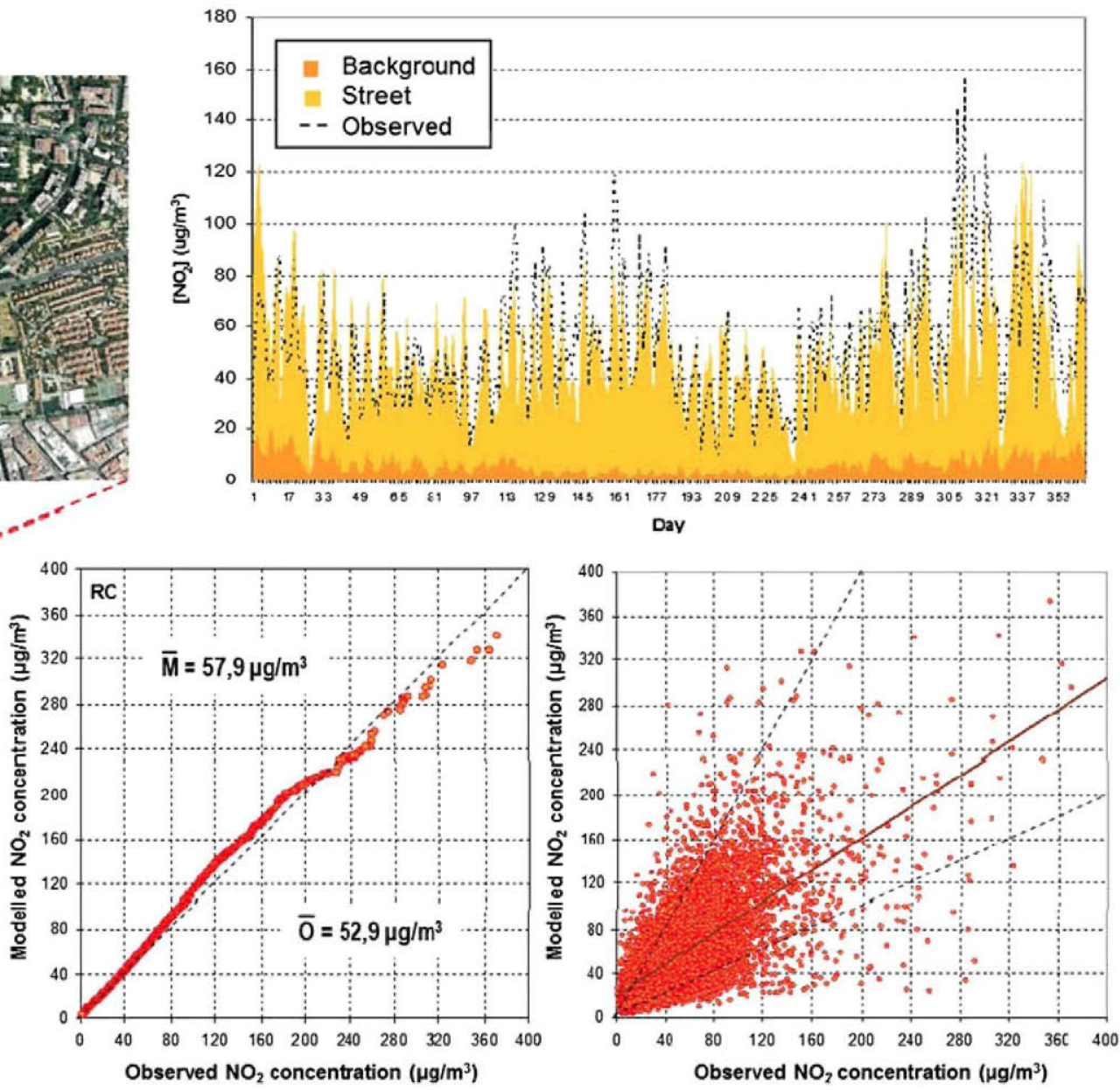

Fig. 3. Location and OSPM results (annual series, Q-Q and scatter plots) for a traffic station. 
et al., 2010b). Consequently, a specific emission inventory has been developed and adapted for each of the four modeling domains in this application. Emission processing was performed with SMOKE in every case.

\subsubsection{Domain 1-Europe (D1)}

Anthropogenic emissions were taken from the EMEP inventory, which consists of a gridded inventory $\left(50 \times 50 \mathrm{~km}^{2}\right)$ that covers Europe completely and which was compiled from national submissions to the Convention on Long-range Transboundary Air Pollution (LRTAP) (Vestreng, 2003). The temporal profiles and vertical distribution needed to resolve the emissions were those used in the EuroDelta experiment (van Loon et al., 2007). Biogenic VOCs (isoprene, monoterpenes and other biogenic volatile organic compounds) have been computed offline (the Global Emission Inventory Activity - GEIA) and processed into SMOKE by implementing the algorithms proposed by Guenther et al. (1996). Both inventories were consistent with the EMEP/CORINAIR methodology used to compute emissions in the Spain's National Emission Inventory (SNEI) (EEA, 2009).

\subsubsection{Domain 2 - Iberian Peninsula (D2)}

The emissions used for this domain were taken from the National Emission Inventories of Spain (SNEI) and Portugal (PNEI) and processed with SMOKE. Hourly, 16-km resolved emissions from 184 area-source categories were used along with detailed information regarding temporal patterns and release conditions of 1720 stacks belonging to 62 point-source categories. The inventory was chemically speciated according to the Carbon Bond CB05 mechanism, a lumped structure chemical mechanism including 156 reactions and 69 species including aerosols (Yarwood et al., 2005). The chemical composition of VOCs, $\mathrm{PM}_{2.5}$ and $\mathrm{NO}_{\mathrm{X}}$ emissions in the inventory was defined through 221 chemical profiles built from the relevant information contained the EMEP/CORINAIR guidebook and the US EPA ESPECIATE database (EEA, 2009; Hsu et al., 2006).

\subsubsection{Domain 3 - Greater Madrid region (D3)}

The emission inventory compilation and implementation for D3 were the results of a thorough intercomparison exercise of two official inventories available for this area, the regional inventory and the regional disaggregation of the SNEI (Fig. 4) (Vedrenne et al., 2012). The analysis relied on the fundamental hypothesis that the accuracy of an emission estimate may be assessed by the degree of agreement between air quality observations and the results of an air quality model (CMAQ) feed with that emission information while keeping all other inputs (meteorology, boundary conditions, etc.) constant (Borge et al., 2010b). The analysis of the differential response of the model at representative points in the modeling domain (Fig. 4) along with the analysis of the differences on alternative emission estimates was used to find out which of the underlying methods and information used in both inventories may provide a more accurate estimate of the actual emissions (total amount, sector share and geographical and temporal distribution) in the Madrid region.

The results confirmed the lack of consistency between national, regional and local emission inventories, which has been a longstanding problem in multi-scale air quality modeling (FAIRMODE,

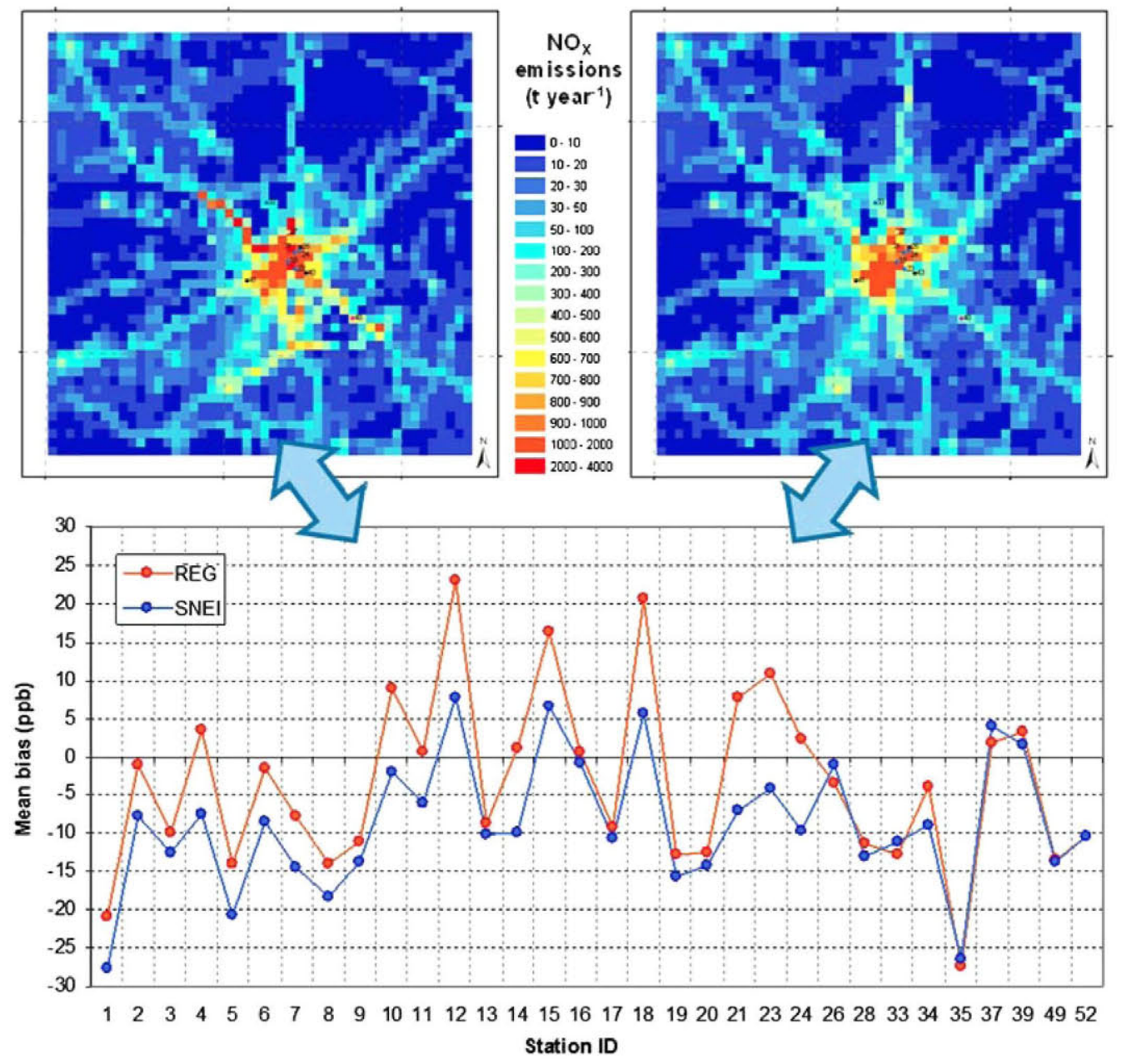

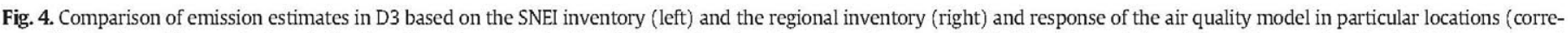

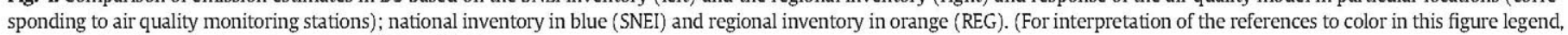
the reader is referred to the web version of this article.) 
Table 2

Summary of emissions (SNAP group level) in D4. Reported in metric tons per year.

\begin{tabular}{|c|c|c|c|c|c|c|c|}
\hline SNAP group & $\mathrm{CO}$ & $\mathrm{NH}_{3}$ & $\mathrm{NO}_{\mathrm{x}}$ & $\mathrm{PM}_{10}$ & $\mathrm{PM}_{2.5}$ & $\mathrm{SO}_{2}$ & VOC \\
\hline 01 - Combustion in energy and transformation industries & 225 & 0 & 243 & 50 & 29 & 1128 & 1 \\
\hline 02 - Non-industrial combustion plants & 10,004 & 0 & 3680 & 520 & 410 & 2731 & 1104 \\
\hline 03 - Combustion in manufacturing industry & 2238 & 0 & 10,689 & 265 & 210 & 2494 & 1217 \\
\hline 04 - Production processes & 1083 & 130 & 108 & 51 & 32 & 70 & 3782 \\
\hline 05 - Extraction and distribution of fossil fuels & 0 & 15 & 0 & 0 & 0 & 0 & 2056 \\
\hline 06 - Solvent and other product use & 0 & 212 & 0 & 0 & 0 & 0 & 48,828 \\
\hline 07 - Road transport & 22,070 & 250 & 27,961 & 1506 & 1205 & 157 & 4365 \\
\hline 08 - Other mobile sources and machinery & 2711 & 0 & 4171 & 360 & 360 & 287 & 769 \\
\hline 09 - Waste treatment and disposal & 441 & 2036 & 1769 & 26 & 26 & 6 & 5267 \\
\hline $10-$ Agriculture & 357 & 1543 & 56 & 90 & 13 & 0 & 17 \\
\hline 11 - Other sources and sinks (Nature) & 32 & 605 & 125 & 0 & 0 & 0 & 4682 \\
\hline Total & 39,161 & 4791 & 48,802 & 2868 & 2285 & 6873 & 72,088 \\
\hline
\end{tabular}

2010). The resulting inventory for D3 was a combination of emission data from both official inventories based on the understanding of the reasons for discrepancies between them. Besides helping to understand which inventory provided a better estimate, the study was useful to identify preliminary ways to conciliate future editions of both inventories.

\subsubsection{Domain 4 - Madrid Metropolitan Area (D4)}

The criteria for the design and computation of the emission inventory for the innermost domain consisted in the combination of bottom-up and top-down methods paying special attention to keep the consistency across domains/inventories, the use of very detailed source-specific methods and the implementation of a flexible and detailed approach in order to reflect the outcome of relevant emission reduction measures. The computations carried out at this stage revealed that road traffic (SNAP group 07) is responsible for $57 \%$ of $\mathrm{NO}_{\mathrm{X}}$ emissions in this modeling domain, as summarized in Table 2. The resulting inventory had the capability to simulate strategies aimed at cutting down emissions from this sector such as implementing low emission zones (access restrictions by vehicle type, age or technology), changing speed limits or allowing penetration of new technologies (combustion engine standards, hybrid and electric vehicles, etc.). It also considered specific fleet turnover and limitations by segments (busses, taxis, light duty vehicles, passenger cars) as well as measures to alleviate urban congestion.

At this scale, the reference model for calculating emissions from road traffic was COPERT 4 (Ntziachristos et al., 2009), which was run for a great number of road links contained in 9 management areas as shown in Fig. 5. Alternatively, emissions from road traffic were computed with HBEFA 3.1, which is a model based on traffic situations (HBEFA, 2012). Further descriptions on the configuration of these models and on the estimation of traffic-related emissions can be found in Borge et al. (2012). The resulting emissions for each vehicle type are referred to link level and have a 1-hour temporal resolution. The subsequent spatial allocation of the emissions within the Eulerian grid was carried out through an overlapping process as

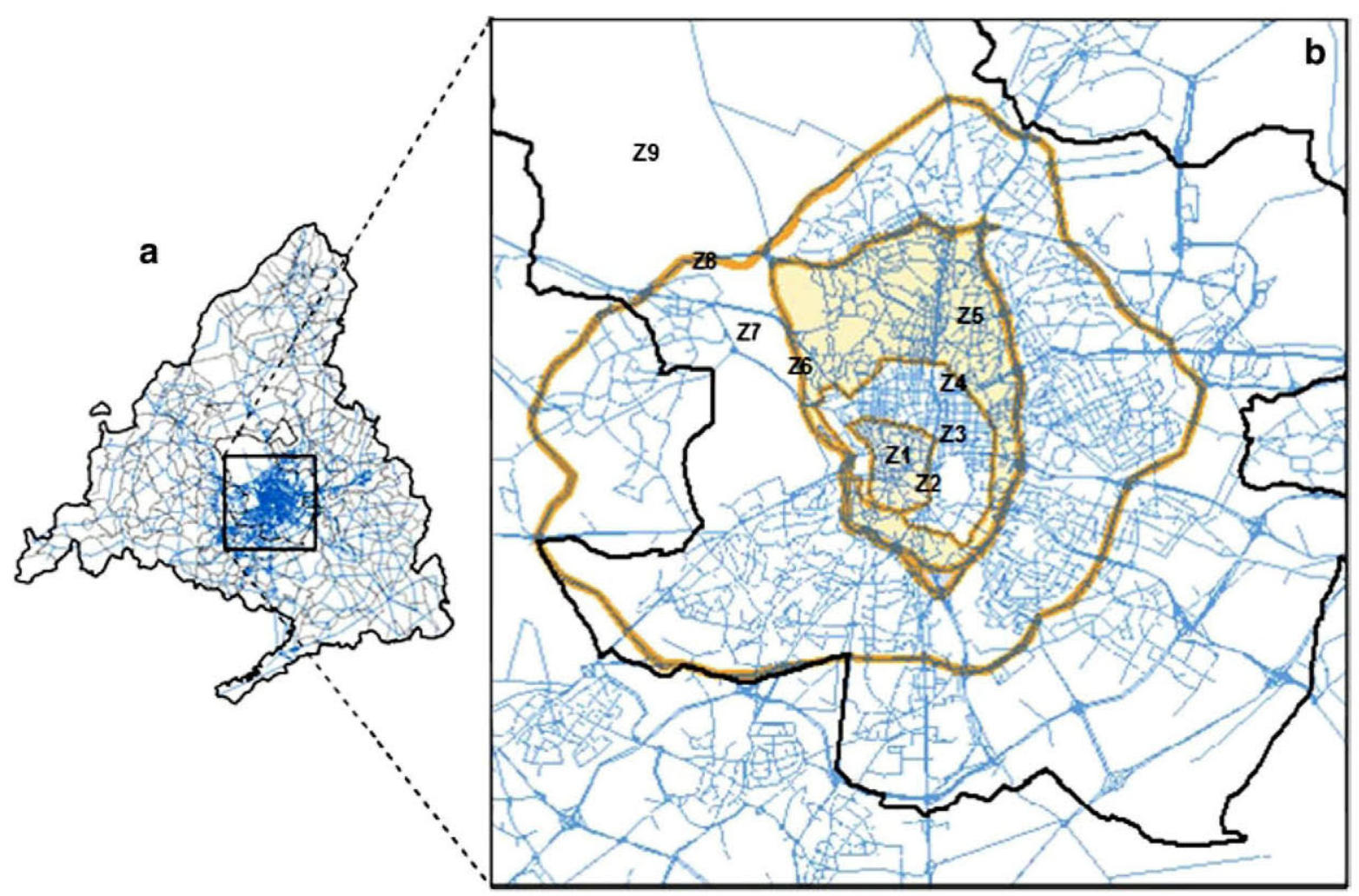

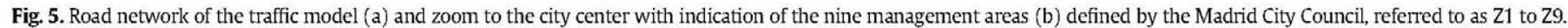




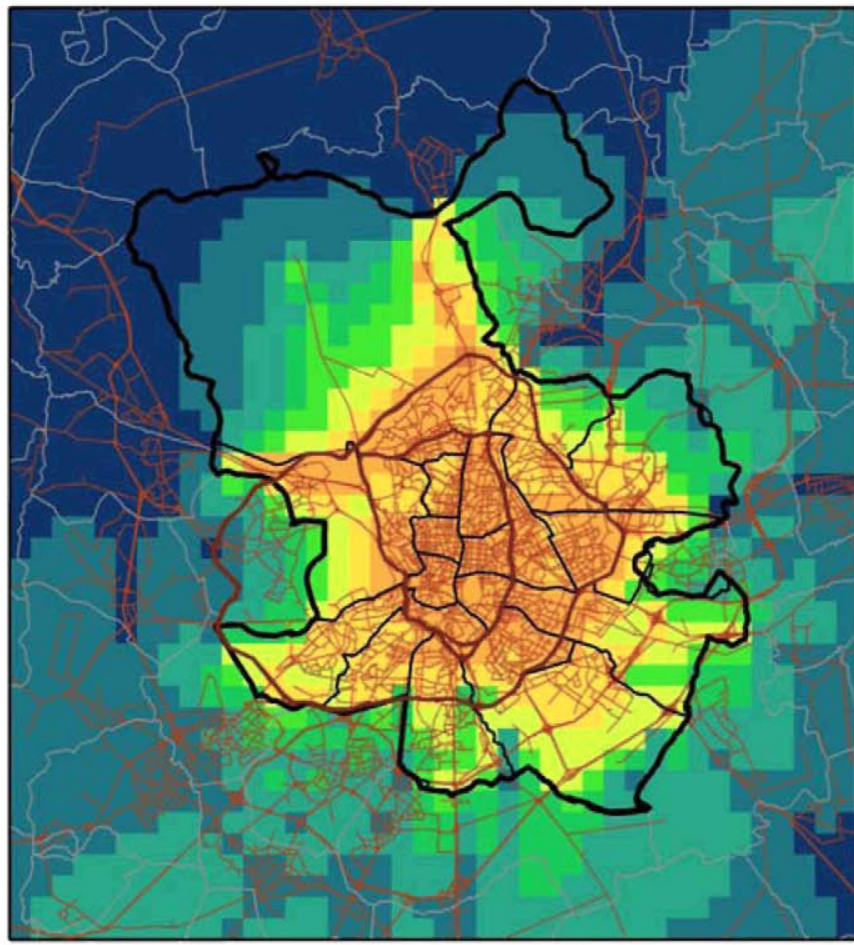

\section{Contribution \\ (\%) to $\mathrm{NO}_{2}$ \\ annual average \\ (local road \\ traffic) \\ $90-100$ \\ $80-90$ \\ $70-80$ \\ $60-70$ \\ $50-60$ \\ $40-50$ \\ $30-40$ \\ $20-30$ \\ $10-20$ \\ $0-10$}

Fig. 6. Result of the source apportionment analysis for the road traffic sector (SNAP group 07)

described in Borge et al. (2008b). Additionally, this procedure allowed providing emissions directly to the street canyon model, which constituted a distinct advantage to keep consistency between the mesoscale and the street-scale models.

Besides road traffic, all the other relevant sectors were represented with a sufficient detail. Relatively important sources such as those of the domestic, residential and commercial sector (SNAP group 02) were inventoried under a bottom-up approach and classified according to their consumed fuel. This issue allows any fuel change or boiler turnover processes to be simple and quickly simulated.

\section{Results and discussion}

Once the emission calculations were accomplished, the modeling system was used to perform a series of analyses and experiments that resulted in the definition of a complete strategy aimed to meet

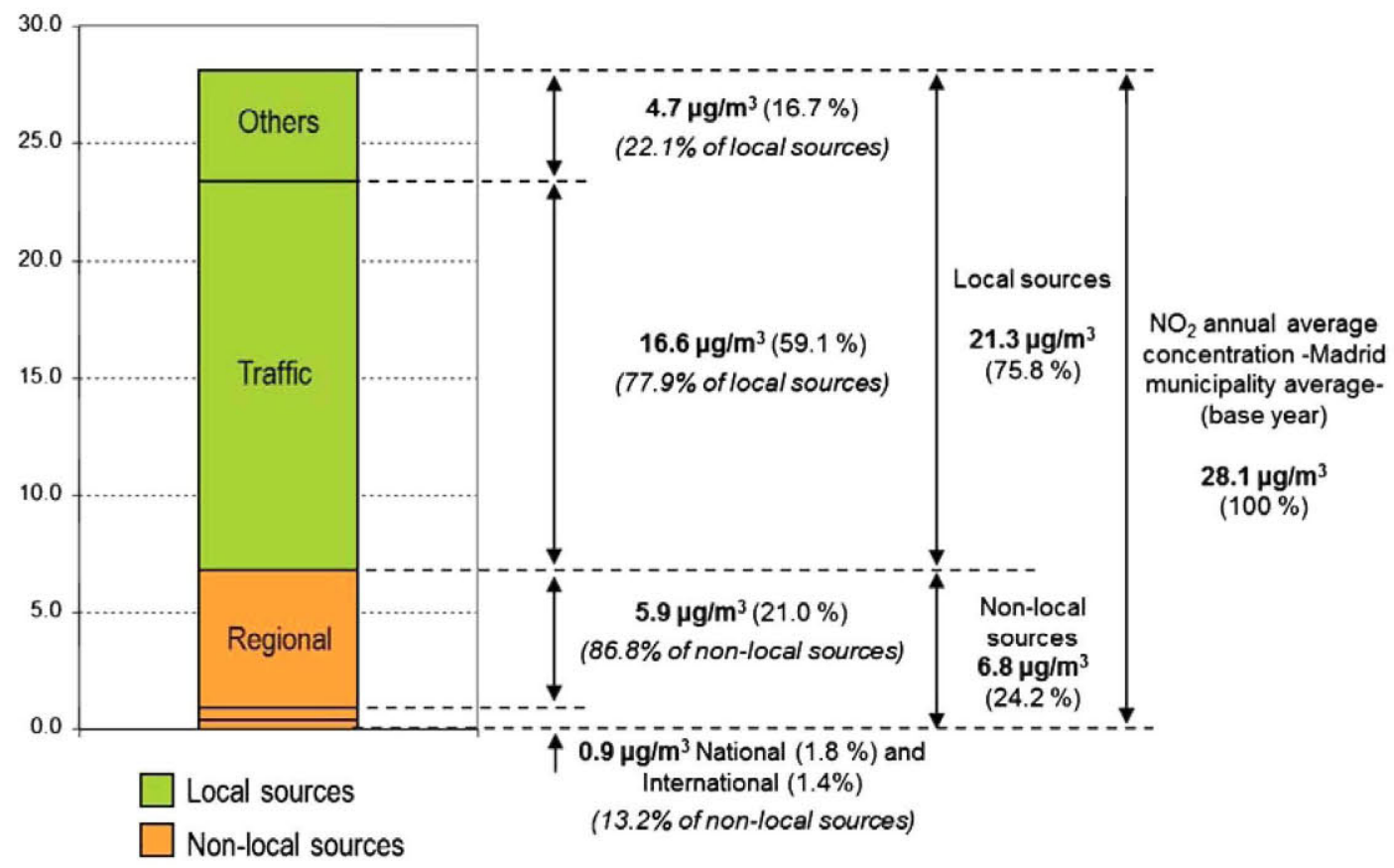

Fig. 7. Result of the source apportionment analysis (annual $\mathrm{NO}_{2}$ mean for the whole Madrid municipality). 
the $\mathrm{NO}_{2}$ air quality standards required by 2015 in Madrid (Madrid City Council, 2012).

\subsection{Source apportionment exercise}

A source apportionment exercise of $\mathrm{NO}_{2}$ levels is usually a necessary procedure to be carried out when developing an AQP intended to demonstrate future compliance under the European legislation as well as to define meaningful abatement options. The analysis for the relevant time period (e.g. annual basis for the $\mathrm{NO}_{2}$ annual LV) provided essential information regarding the basic emission abatement strategy/course of action, a maximum feasible air quality improvement related to the main emitting sectors and a series of external constrains.

A zero-out methodology was followed in this application. The contribution of a particular emission source or region can be estimated through the brute force method (BFM), sometimes referred to as single-perturbation method (Samaali et al., 2011 and references within). This method relies on the analysis of the change in the pollutant concentration that would occur if a given emitting source is removed from the simulation (usually referred to as zero-out sensitivity runs). This approach has been used in the past to isolate the response of complex, nonlinear systems to one particular sector in source apportionment and sensitivity analysis (Cohan et al., 2005). This method has inherent limitations in accurately describing sensitivities but it may be useful to approximate the effect of potential emission reductions in a particular source or origin area as pointed out before in several studies (Koo et al., 2009; Carmichael and Wild, 2010; Leung et al, 2007).

Reductions of $100 \%$ (zero-out) were simulated for the most relevant anthropogenic emissions, including road transport, industry, aviation and residential, commercial and institutional combustion (RCI). The total impact and therefore the maximum theoretical benefits that can be harvested by implementing abatement options in these sectors were derived from the comparison of the assessment of the individual runs with the base case (considering all emissions). This premise is illustrated in Fig. 6, from which it can be seen that reductions of up to $90 \%$ can be achieved theoretically after applying restrictions only to the road traffic sector. Moreover, reductions decrease with the distance to the city center, witnessing the preponderance of road traffic as the main polluting activity for an urban environment such as Madrid.

A similar approach was followed to estimate the contributions of different geographic areas. In this case outputs from CMAQ runs using
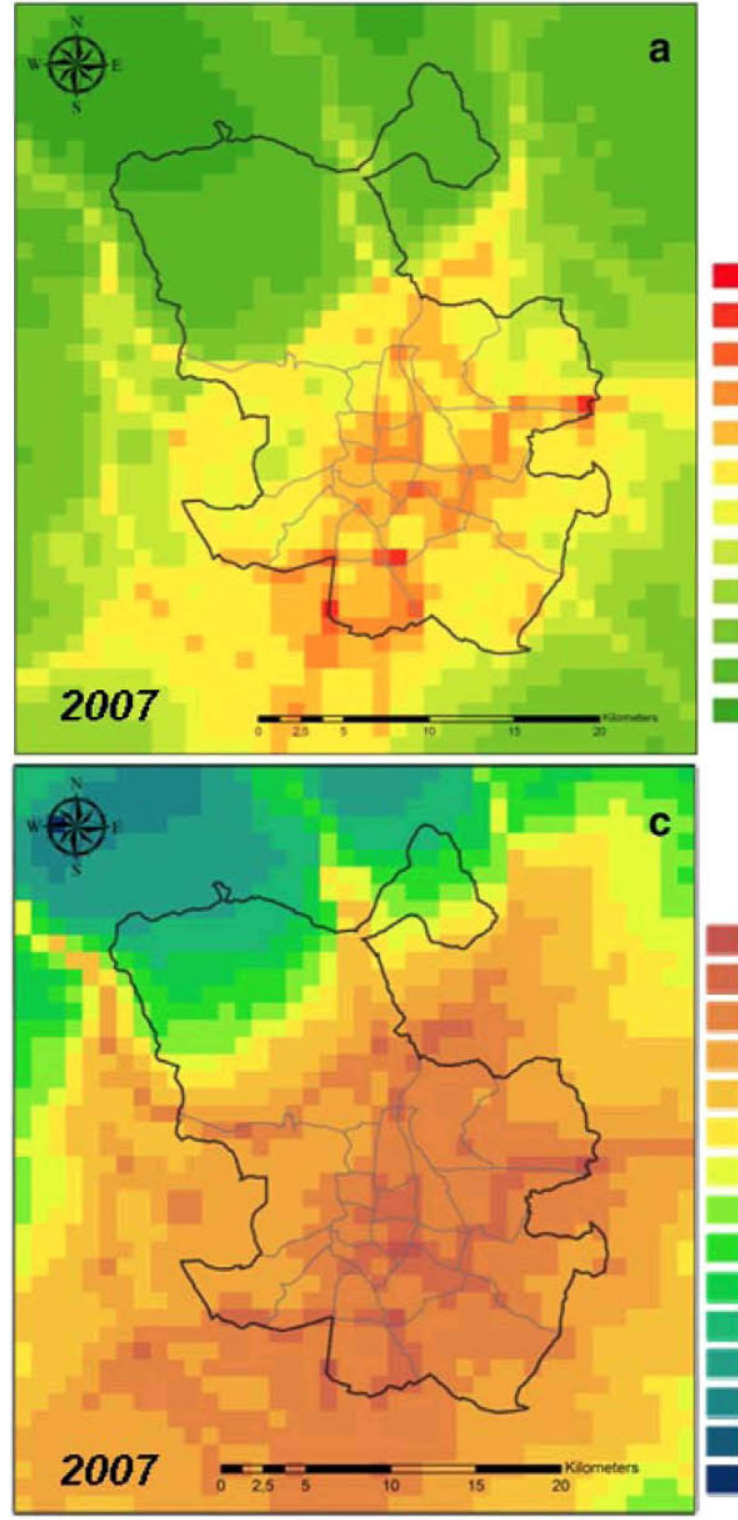
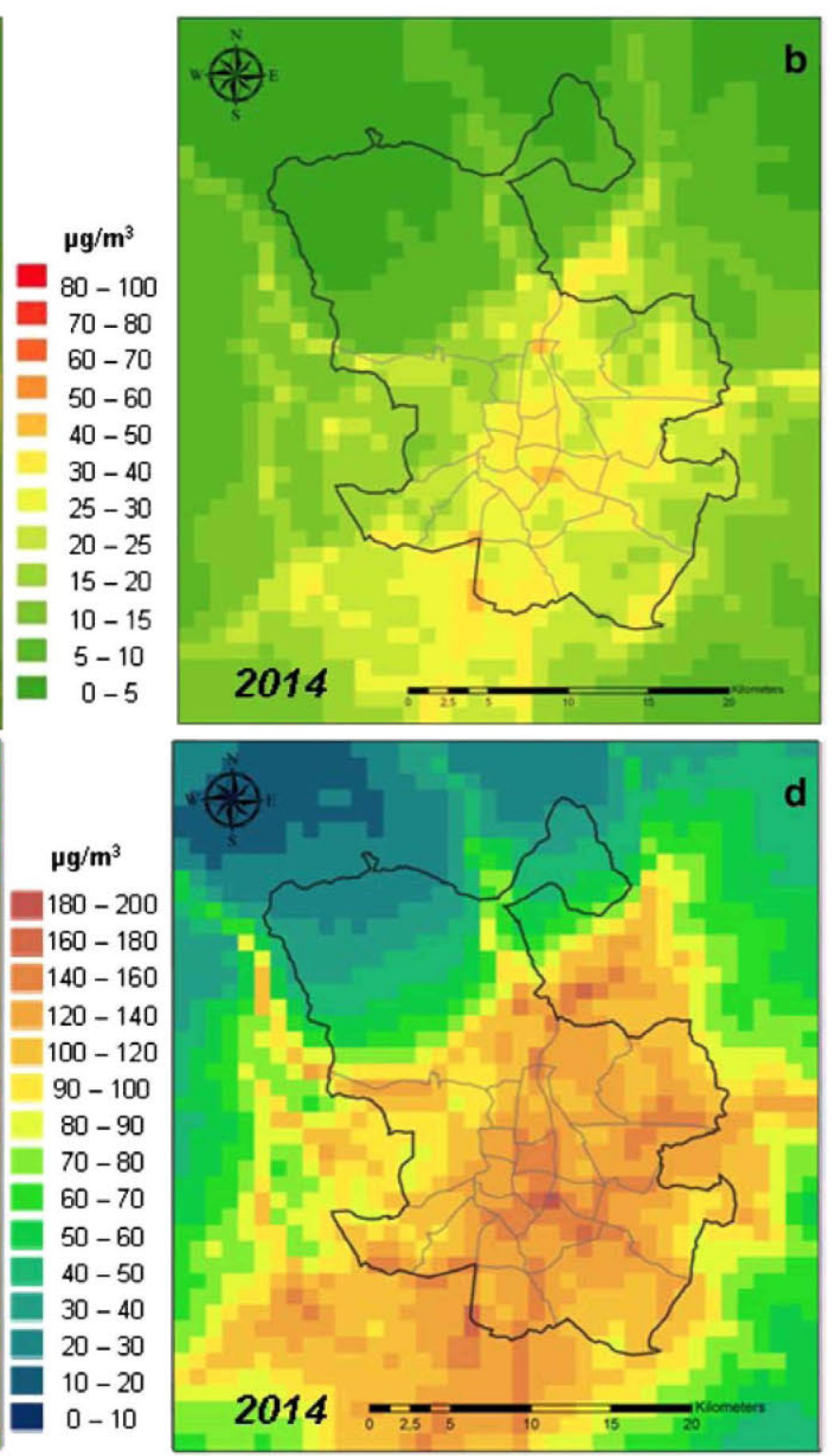

Fig. 8. Expected effect of the Madrid $\mathrm{AQP}$ in $\mathrm{NO}_{2}$ concentration: annual limit value (a-b) and 1-hour limit value (c-d). 
alternative boundary conditions and geographical masks (i.e. setting to zero the emissions in grid cells corresponding to a given administrative division, such as the municipalities of the Madrid Greater Region other than Madrid) were compared in order to derive the amount of $\mathrm{NO}_{2}$ that can be related to different origin areas. Fig. 7 shows the average geographic apportionment structure for the entire Madrid municipality. This confirmed that Madrid is strongly dominated by local sources (76\%), mainly road traffic, contributing up to $16.6 \mu \mathrm{g} / \mathrm{m}^{3}$ to the annual $\mathrm{NO}_{2}$ value as an average over the Madrid municipality (nearly $80 \%$ of local contributions). Other local sources (mainly $\mathrm{RCI}$ and waste management) had a much lower influence, roughly $5 \mu \mathrm{g} / \mathrm{m}^{3}$ (around $20 \%$ of local contributions). The regional influence accounted for approximately $20 \%$ of the total mean concentration $\left(5.9 \mathrm{\mu g} / \mathrm{m}^{3}\right)$, while the national and international influences were negligible (less than $1 \mu \mathrm{g} / \mathrm{m}^{3} \mathrm{com}$ bined). In this context, regional refers to other municipalities within the Madrid Greater Region and national refers to locations beyond the Madrid Greater Region.

It should be noted that non-local sources cannot be directly regulated or controlled by the Madrid City Council and therefore are outside the scope of any local plan or policy. However, most of the regional contribution originates in adjacent municipalities that are part of the Madrid metropolitan area where emissions are also strongly dominated by the road traffic sector. These results indicated that an efficient AQP for Madrid should include measures aimed at limiting local road traffic with an additional effect at the whole metropolitan area.

\subsection{Emission scenario}

Complementing the source apportionment exercise, the development and modeling of a future-year emission scenario is a crucial stage for the design of effective abatement options and assessment of the compliance with air quality standards (Boogaard et al., 2012). Since there are no universal solutions to improve air quality, the particular features of any reduction plan will depend on the causes of poor air quality levels. Future-year emission estimates should be consistent with the methods applied for the base year emission inventory compilation (Int Panis et al., 2004). Changes or updates of computation methods may lead to important deviations in future year estimates and therefore misleading information about the effectiveness of particular measures. For instance, preliminary experiments revealed important differences (up to $20 \%$ ) in $\mathrm{NO}_{\mathrm{X}}$ emissions for the Madrid metropolitan area depending on the road traffic emission model used. Important differences were also found in critical parameters such as the $\mathrm{NO}_{\mathrm{X}}$ emission speciation ( $\mathrm{NO} / \mathrm{NO}_{\mathrm{X}}$ ratio) for future engine technologies. Further analysis on this issue and examples of consistent emission projection methods are provided in Lumbreras et al. (2008).

Up to 70 abatement measures have been assessed and evaluated for the final definition of the Madrid AQP. Consistently with the results of the source apportionment exercise performed, most of the measures were targeted to the road traffic sector. Measures such as the definition of a Low Emission Zone (LEZ), reduction of road capacity and pedestrianized areas in the city center, and renovation of city bus fleet to incorporate clean technologies (electric, hybrid natural gas-fuelled busses) would achieve a $40 \%$ reduction of $\mathrm{NO}_{\mathrm{X}}$ emissions from the road traffic sector in the modeling domain. Further details can be found in Madrid City Council (2012). As a result of all the measures included in the $\mathrm{AQP}$, a global decrease of $31 \%$ in $\mathrm{NO}_{\mathrm{X}}$ emissions is expected in the year 2014 within D4 (respective to the emissions of 2007 used as reference scenario or base year). Emissions, surrogate data and speciation profiles were updated to reflect the expected composition of fleet and other structural measures (expansion of the regulated parking system, regulation of the working schedule of taxis, etc.). This is also relevant for measures affecting other sectors such as fuel switch in domestic boilers or upgrades of engines and other equipment in waste water plants. The simulation of $\mathrm{NO}_{2}$ ambient concentration values corresponding to this emission scenario pointed out that compliance with LV could be achieved in Madrid by 2015. Fig. 8 compares CMAQ outputs for 2007 (base year) and 2014 (implementation of the AQP). From this comparison it can be inferred that annual $\mathrm{NO}_{2}$ levels may be reduced by $34 \%$ as an average; approximately $15 \mu \mathrm{g} / \mathrm{m}^{3}$ in the city center, also with an important impact in the metropolitan area $\left(-7 \mu \mathrm{g} / \mathrm{m}^{3}\right.$ as an average in the modeling domain). 1-hour concentration peaks may also decline by $40 \%$ approximately in most of the city.

The modeling platform was also useful to estimate the effect of additional measures that may be applied under exceptional conditions or short-term exceedance situations (such as those produced under unfavorable meteorological conditions), as illustrated in Fig. 9. This can be accomplished by conveniently changing emission figures and
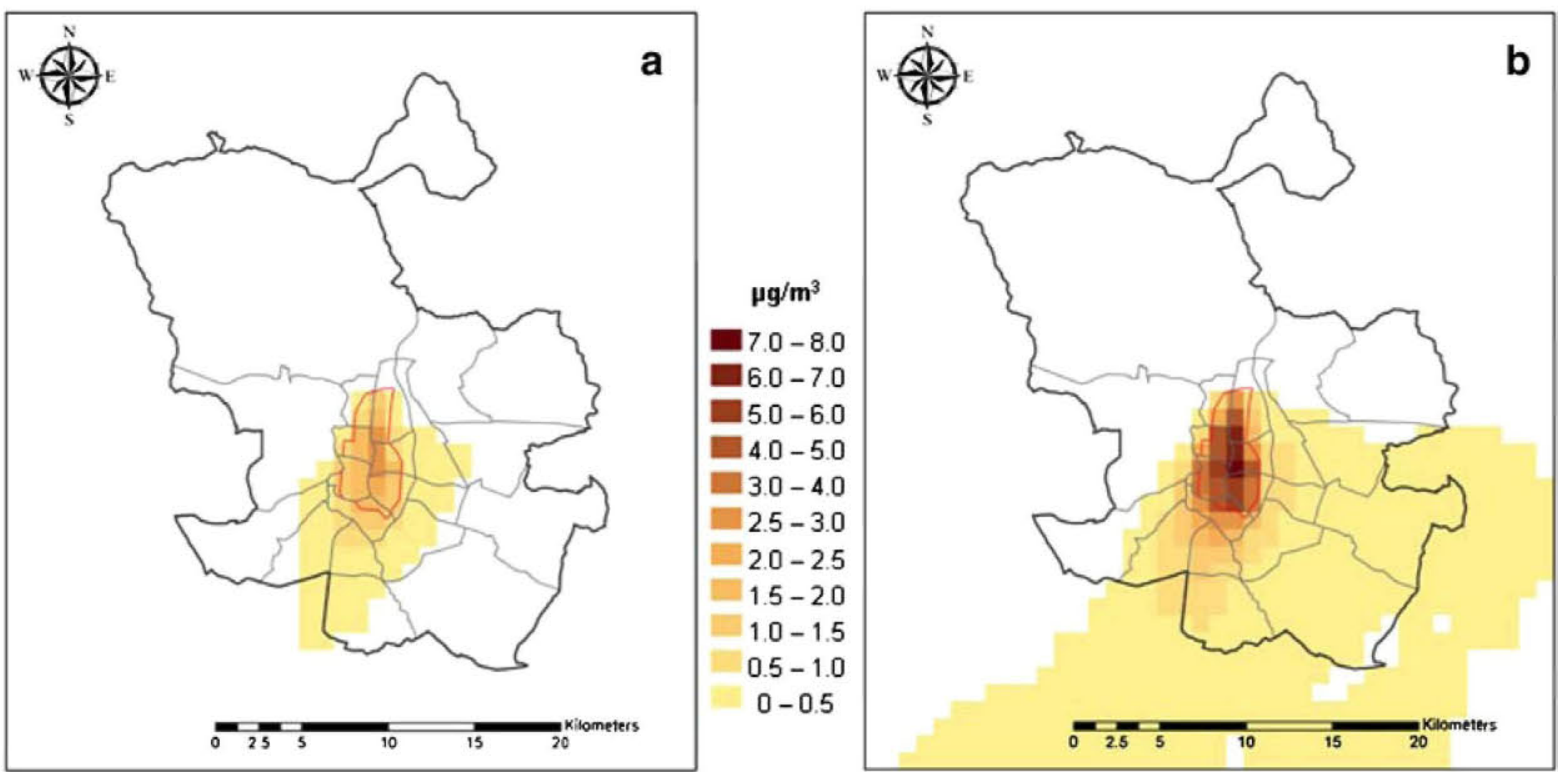

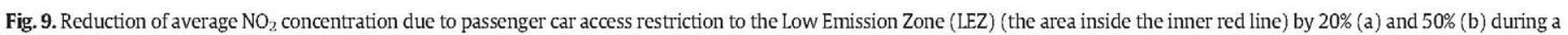
24-h period under unfavorable meteorological conditions. (For interpretation of the references to color in this figure legend, the reader is referred to the web version of this article.) 
surrogate data for specific SMOKE activities (linked to specific vehicle types and management areas). The same emissions can be used to feed the street-scale OSPM model to complement the analysis providing thus relevant information regarding compliance expectancy in hot spots.

\section{Conclusions}

The development and assessment of an AQP in an urban area constitute a very complex task from the air quality-modeling point of view. The definition of effective abatement measures implies the need of a previous analysis of source apportionment regarding both the geographic origin of pollutants and the identification of sources responsible for their emission. These analyses involve rather different temporal and spatial scales and require the combination and harmonization of models and data. Emission inventories play a crucial role in this context since the assessment of a given measure will entirely depend on how accurate is the representation of that measure in terms of emissions. Therefore, the emission processing system used in this kind of applications should be able to combine information from a variety of sources and it needs to be flexible and detailed enough to reflect the outcome of relevant emission reduction measures.

This paper summarizes the modeling activities carried out in Madrid (Spain) to develop an $\mathrm{AQP}$ to comply with the annual $\mathrm{NO}_{2}$ European standards. The study shows that the SMOKE system is able to accommodate emissions from at least four emission inventories from the European scale EMEP inventory to a very detailed bottom-up emission inventory for the Madrid city.

The present study implemented a series of good practices that are recommendable when developing scenarios. This included focusing on the abatement measures on the emission sectors responsible for air pollution, according to the developed source apportionment study, the use of a projection model consistent with emission inventories, as well as transparent practices.

The source apportionment exercises made for Madrid AQP indicate that $\mathrm{NO}_{2}$ ambient concentration values are strongly dominated by local sources with a remarkable contribution from road traffic. Therefore, a package of 70 measures, mostly targeted at this sector, was proposed and simulated. According to the results of this study, this scenario would cut down $\mathrm{NO}_{\mathrm{x}}$ emissions by $31 \%$ and would allow the fulfillment of $\mathrm{NO}_{2}$ limit values in Madrid by the end of 2014 .

\section{Conflict of interest}

There is no conflict of interests.

\section{Acknowledgments}

The Madrid City Council provided the traffic model and supported this study. The CMAQ modeling system was made available by the US EPA and it is supported by the Community Modeling and Analysis System (CMAS) Center. The authors also acknowledge the use of emission datasets and monitoring data from the Spanish and Portuguese Ministries of Environment.

\section{References}

Ariztegui J, Casanova J, Valdes M. A structured methodology to calculate traffic emissions inventories for city centres. Sci Total Environ 2004;334-335:101-9.

Beelen R, Hoek G, Pebesma E, Vienneau D, de Hoogh K, Briggs DJ. Mapping of background air pollution at fine spatial scale across the European Union. Sci Total Environ 2009;6: $1852-67$.

Berkowicz RM, Ketzel RM, Jensen SS, Hvidberg M, Raaschou-Nielsen O. Evaluation and application of OSPM for traffic pollution assessment for a large number of street locations. Environ Model Softw 2008;23:296-303.

Boogaard $\mathrm{H}$, Janssen NAH, Fischer PH, Kos GPA, Weijers EP, Cassee FR, et al. Impact of low emission zones and local traffic policies on ambient air pollution concentrations. Sci Total Environ 2012;1:132-40.
Borge R, Lumbreras J, Rodríguez ME. Integrated assessment modeling in Spain. US EPA 16th Annual International Emission Inventory Conference: emission inventories: integration, analysis, and communications; 2007. [Raleigh, 16 pp., Available at: http://www.epa.gov/tnn/chief/conference/ei16/session1/borge.pdf].

Borge R, Alexandrov V, del Vas JJ, Lumbreras J, Rodríguez E. A comprehensive sensitivity analysis of the WRF model for air quality applications over the Iberian Peninsula. Atmos Environ 2008a;42:8560-74.

Borge R, Lumbreras J, Rodríguez ME. Development of a high-resolution emission inventory for Spain using the SMOKE modelling system: a case study for the years 2000 and 2010. Environ Model Softw 2008b;23:1026-44.

Borge R, Lumbreras J, de la Paz D, Rodríguez ME. Air quality modelling. Bridging national and continental scales. 18th World IMACS/MODSIM Congress, Cairns; 2009. p. 2293-9.

Borge R, López J, Lumbreras J, Narros A, Rodríguez E. Influence of Boundary conditions on CMAQ simulations over the Iberian Peninsula. Atmos Environ 2010a;44:2681-95.

Borge R, Lumbreras J, de la Paz D, Dilara P, Tarrasón L. Urban emissions and projections. Proceedings of the 13th International Conference on harmonization within atmospheric dispersion modelling for regulatory purposes2-8681-5062-4; 2010b. p. 991 [Paris].

Borge R, de Miguel I, de la Paz D, Lumbreras J, Perez J, Rodríguez ME. Comparison of road traffic emission models in Madrid (Spain). Atmos Environ 2012;62:461-71.

Byun DW, Ching JKS. Science algorithms of the EPA models-3 Community Multi-scale Air Quality (CMAQ) modeling system. EPA/600/R-99/030, US EPA National Exposure Research Laboratory, North Carolina; 1999.

Byun DW, Schere KL. Review of the governing equations, computational algorithms, and other components of the Models-3 community Multiscale Air Quality (CMAQ) modeling system. Appl Mech Rev 2006;59:51-77.

Carmichael G, Wild O. Global and regional modelling. Hemispheric transport of air pollution. Task force on hemispheric transport of air pollution; 2010. [Available at: www. htap.org].

Cohan DS, Hakami A, Hu Y, Russell AG. Nonlinear response of ozone to emissions: source apportionment and sensitivity analysis. Environ Sci Technol 2005;39:6739-48.

Denby B, Douros I, Fragkou L. Modelling of nitrogen dioxide $\left(\mathrm{NO}_{2}\right)$ for air quality assessment and planning relevant to the European Air Quality Directive. Forum for Air Quality Modelling in Europe (FAIRMODE) guidance document; 2011.

European Commission. Joint Research Centre (JRC)/Netherlands Environmental Assessment Agency (PBL). Emission Database for Global Atmospheric Research (EDGAR); 2009 [Release version 4.0].

European Environment Agency (EEA). EMEP/EEA air pollutant emission inventory guidebook - 2009. EEA Technical Report No. 9/20091725-2237; 2009.

European Environment Agency (EEA). Air quality in Europe - 2011 report. EEA Technical Report No 12/2011978-92-9213-232-3; 2011. [Available online at: http://www.eea. europa.eu/publications/air-quality-in-europe-2011].

European Environmental Agency (EEA). Air quality in Europe - 2012 report. EEA Report No 4/20121725-9177; 2012. [Available online at: http://www.eea.europa.eu/publications/air-quality-in-europe-2012].

FAIRMODE. Background document on the emission needs at local scale for AQ modelling (Working Group 2, subgroup 3); 2010 [http://fairmode.ew.eea.europa.eu/fol404948/ sg3_background_document_oct10_draft.pdf].

Giannouli M, Kalognomou EA, Mellios G, Moussiopoulos N, Samaras Z, Fiala J. Impact of European emission control strategies on urban and local air quality. Atmos Environ 2011;45:4753-62.

Grice S, Stedman J, Kent A, Hobson M, Norris J, Abbott J, et al. Recent trends and projections of primary $\mathrm{NO}_{2}$ emissions in Europe. Atmos Environ 2009;43:2154-67.

Guenther AB, Greenberg J, Helmig D, Klinger L, Vierling L, Zimmerman P, et al. Leaf, branch, stand and landscape scale measurements of volatile organic compound fluxes from US. woodlands. Tree Physiol 1996;16:17-24.

Guerreiro C, Horálek J, de Leeuw F, Hak C, Nagl C, Kurfürst P, et al. Status and trends of NO. ambient concentrations in Europe. ETC/ACC Technical Paper 19/2010; 2010. [Available online at: http://acm.eionet.europa.eu/reports/docs/ETCACC_TP_2010_19_NO2trends. pdf].

HBEFA. Handbuch Emissionsfaktoren des Strassenverkehrs 3.1-Dokumentation. Infras. UBA. Vienna: BUWAL-UBA. www.hbefa.net, 2012. [Available from].

Ho BQ Clappier A. Road traffic emission inventory for air quality modelling and to evaluate the abatement strategies: a case of Ho Chi Minh City, Vietnam. Atmos Environ 2011;45:3584-93.

Hsu Y, Strait R, Roe S, Holoman D. SPECIATE 4.0. Speciation Database Development Documentation. Final Report. EPA contract. Nos. EP-D-06.001, work assignment Numbers 0-03 and 68-D-02-063, WA 4-04 and WA 5-05. EPA/600/R-06/16. http://www.epa. $\mathrm{gov} / \mathrm{ttn} / \mathrm{chief} / \mathrm{software} /$ speciate/speciate4/documentation/speciatedoc_1206.pdf, 2006. [Available from].

Institute for the Environment. SMOKE v2.7 user's manual. Chapel Hill, NC: University of North Carolina; 2009 [Available online at: http://www.smoke-model.org/version2 7/html/ch01.html].

Int Panis L, De Nocker L, Cornelis E, Torfs R. An uncertainty analysis of air pollution externalities from road transport in Belgium in 2010. Sci Total Environ 2004;334-335: 287-98.

Karanasiou A, Moreno T, Amato F, Lumbreras J, Narros A, Borge R, et al. Road dust contribution to PM levels - evaluation of the effectiveness of street washing activities by means of positive matrix factorization. Atmos Environ 2011;45:2193-201.

Kassomenos P, Karakitsios S, Papaloukas C. Estimation of daily traffic emissions in a South-European urban agglomeration during a workday. Evaluation of severa "what if" scenarios. Sci Total Environ 2006;2-3:480-90.

Koo B, Wilson GM, Morris RE, Dunker AM, Yarwood G. Comparison of source apportionment and sensitivity analysis in a particulate Matter Air Quality Model. Environ Sc Technol 2009;43:6669-75. 
Latza U, Gerdes S, Baur X. Effects of nitrogen dioxide on human health: systematic review of experimental and epidemiological studies conducted between 2002 and 2006. Int J Hyg Environ Health 2009;212:271-87.

Lee T, Park J, Kwon S, Lee J, Kim J. Variability in operation-based NOx emission factors with different test routes, and its effects on the real-driving emissions of light diese vehicles. Sci Total Environ 2013;461-462:377-85.

Leung FYT, Logan JA, Park R, Hyer E, Kasischke E, Streets D, et al. Impacts of enhanced biomass burning in the boreal forests in 1998 on tropospheric chemistry and the sensitivity of model results to the injection height of emissions. J Geophys Res 2007;112. http://dx.doi.org/10.1029/2006]D008132. [D10313].

Liu H, He K, Lents JM, Wang Q Tolvett S. Characteristics of diesel truck emission in China based on portable emissions measurement systems. Environ Sci Technol 2009;43: 9507-11.

Lumbreras J, Borge R, de Andres JM, Rodriguez ME. A model to calculate consistent atmospheric emission projections. Application to Spain. Atmos Environ 2008;42(21): 5251-66.

Madrid City Council. Madrid's Air Quality Plan 2011-2015. Approved by the governing board of Madrid City Council on April 26, 2012. General Directorate of Sustainability, Government Division of Environment, Safety and Mobility, Madrid City Council. http://www.madrid.es/UnidadesDescentralizadas/Sostenibilidad/Otros/ AirQualityPlan\%202011-15.pdf, 2012. [Available online at].

Monteiro A, Miranda AI, Borrego C, Vautard R. Air quality assessment for Portugal. Sc Total Environ 2007;1:22-31.

Moussiopoulos N, Vlachokostas Ch, Tsilingiridis G, Douros I, Hourdakis E, Naneris C, et al Air quality status in Greater Thessaloniki Area and the emission reductions needed for attaining the EU air quality legislation. Sci Total Environ 2009;4:1268-85.

Ntziachristos L, Gkatzoflias D, Kouridis C, Samaras Z. COPERT: a European road transport emission inventory model. In: Athanasiadis IN, Mitkas PA, Rizzoli AE, Marx Gómez J, editors. Information technologies in environmental engineering. Springer; 2009. p. 491-504

Pouliot G, Pierce T, van der Gon HD, Schaap M, Moran M, Nopmongcol U. Comparing emission inventories and model-ready emission datasets between Europe and North America for the AQMEII project. Atmos Environ 2012;53:4-14.

Russell A, Dennis R. NARSTO critical review of photochemical models and modelling Atmos Environ 2010;34:2261-82

Samaali M, Bouchet VS, Moran MD, Sassi M. Application of a tagged-species method to source apportionment of primary PM2.5 components in a regional air quality model. Atmos Environ 2011;45:3835-47.
Simmons WA, Seakins PW. Fstimations of primary nitrogen dioxide exhaust emissions from chemiluminescence NOx measurements in a UK road tunnel. Environ Sci Technol 2012;438:248-59.

Skamarock WC, Klemp JB. A time-split nonhydrostatic atmospheric model. J Comput Phys 2008;227:3465-85.

Sowden M, Cairncross E, Wilson G, Zunckel M, Kirillova E, Reddy V, et al. Developing a spatially and temporally resolved emission inventory for photochemical modeling in the City of Cape Town and assessing its uncertainty. Atmos Environ 2008;30: 7155-64.

Sturm PJ, Sudy C, Almbauer RA, Meinhart J. Updated urban emission inventory with a high resolution in time and space for the city of Graz. Sci Total Environ 1999;235:111-8.

Van Loon M, Vautard R, Schaap M, Bergström R, Bessagnet B, Brandt J, et al. Evaluation of long-term ozone simulations from seven regional air quality models and their ensemble average. Atmos Environ 2007;41:2083-97.

Vardoulakis S, Fisher BEA, Pericleous K, Gonzalez-Flesca N. Modelling air quality in street canyons: a review. Atmos Environ 2003;37:155-82.

Vardoulakis S. ValiantisM, Milner J, ApSimon H. Operational air pollutionmodelling in the UK - street canyon applications and challenges. Atmos Environ 2007;41: 4622-37.

Vardoulakis S, Solazzo E, Lumbreras J. Intra-urban and street scale variability of BTEX, $\mathrm{NO}_{2}$ and $\mathrm{O}_{3}$ in Birmingham, UK: implications for exposure assessment. Atmos Environ 2011:45:5069-78.

Vedrenne M, Borge R, de la Paz D, Lumbreras J, Rodríguez ME. Comparison and assessment of two emission inventories for the Madrid Region. In: Longhurst JWS, Brebbia CA editors. Air pollution XX. Southampton: WIT Press; 2012. p. 12.

Venegas LE, Mazzeo NA. Modelling of urban background pollution in Buenos Aires City (Argentina). Environ Model Softw 2006;21:577-86.

Vestreng V. EMEP/MSC-W technical report. Review and revision. Emission data reported to CLRTAP. MSC-W Status Report 2003. EMEP/MSC-W Note 1/20030804-2446; 2003.

Vlachokostas Ch, Achillas Ch, Moussiopoulos N, Hourdakis E, Tsilingiridis G, Ntziachristos I, et al. Decision support system for the evaluation of the urban air pollution control options: application for particulate pollution in Thessaloniki, Greece. Sci Total Environ 2009;23:5937-48

Yarwood G, Rao S, Yocke M, Whitten G. Updates to the carbon bond chemical mechanism CB05. Final Report to the US EPA, RT-0400675; 2005 [Available from http://www. camx.com/publ/pdfs/CB05 Final Report_120805.pdf]. 